\title{
MUNICIPAL HOME RULE IN CALIFORNIA
}

BY PROFESSOR THOMAS H. REED ${ }^{1}$

Berkeley

$\mathbf{I}^{\mathrm{T}}$

T CAME from Missouri. The convention which in 1879 drafted the present constitution of California was much influenced throughout its deliberations by the Missouri constitution completed but four years earlier. ${ }^{2}$ It was only natural, therefore, that the San Francisco delegation should have seen hope for the municipal independence of their city in the unique provisions of the Missouri document permitting cities of over 100,000 inhabitants to prepare through boards of freeholders charters for their peculiar needs. ${ }^{3}$ The discussion which became quite heated upon this somewhat original proposition led to very serious modifications of the Missouri plan. The fear that San Francisco, the only city of 100,000 inhabitants would become practically independent of the state suggested the provision that the charters should be subject to approval by the legislature, while, at the same time, the aversion to special legislation, strong in the hearts of these constitution-makers, dictated that this approval must be of the charter as a whole without amendment. The provision that charters must provide for a mayor and a two-chamber council which had seemed wise to the Missourians, appealed not at all to the assembled wise men of California, and they omitted it. The number of freeholders to be chosen to draft the charter were thirteen in Missouri, but the Golden State, like some hotels, declined to court misfortune by including this unlucky number in its constitution. The quota of freeholders was therefore fixed at fifteen. With these changes the Missouri plan became engrafted on the fundamental law of California.4

Of course at the time of their adoption these provisions were intended for the sole benefit of the two great cities of St. Louis and San Francisco. The former had already adopted a charter by the new method before the California convention began its operations. ${ }^{5}$ It took San Francisco, how-

$1 \mathrm{Mr}$. Reed is associate professor of government in the University and was for a time secretary to Governor Hiram W. Johnson, so he combines the practical and the academic point of view.

This paper was read at the Los Angeles Meeting of the National Municipal League.

${ }^{2}$ Debates and Proceedings of the Constitutional Convention of the State of California, remarks of Mr. Hager, p. 1059.

${ }^{3}$ Missouri constitution, art. ix, sec. 16, et seq. Thorpe, American Charters, Constitutions and Organic Laws, pp. 2256-2258; also Debates and Proceedings, op. cit., p. 105, et seq.

${ }^{4}$ Constitution of California, art. xi, sec. 8, original section. See E. F. Treadwell, The Constitution of the State of California (ed. 1911), p. 3003.

${ }^{5}$ Horace E. Deming, Government of American Cities, p. 93. 
ever, twenty years and several abortive efforts to actually secure a freeholder charter, which went into effect on January $1,1900 .^{6}$

In the meantime, California had traveled far beyond Missouri on the way to municipal home rule. In 1887 the constitution was amended so as to extend the privilege of framing their own charters to cities of over 10,000 inhabitants. $^{7}$ Immediately four of the larger cities of the state, Los Angeles, Oakland, Stockton and San Diego, elected boards of freeholders and submitted charters which were approved by the legislature in $1889 .{ }^{8}$ The popularity of homemade charters brought about the inclusion of cities above 3500 population in the favored class. ${ }^{9}$ The original clause had provided, in imitation of Missouri, that the charter might be amended at intervals of not less than two years by proposals submitted by the legislative authority of the city to the qualified electors thereof, and subsequently to the senate and assembly of the state. ${ }^{10}$ This portion of the section was amended in 1902 by making mandatory the submission of such proposals whenever 15 per cent of the qualified electors joined in petitioning the legislative authority to so submit them. ${ }^{11}$ The courts had held that the right to make a freeholder charter was not a "continuing right" and that once exercised all changes must be by way of amendment to this original document. ${ }^{12}$ Numerous' amendments to charters were ratified by the legislature in the sessions of 1903 and 1905, and it became obvious that it might greatly serve the interest of simplicity and consistency to permit a city to frame a charter de novo. The legislature of 1905 therefore submitted to the people an amendment authorizing cities of over 3500 population not only to frame a charter, but having framed such a charter to "frame a new one."13 The reform legislature of 1911 submitted the last and most important of all the amendments.

The present section of the constitution provides that the initial' steps for the election of a board of freeholders may be taken either by the council directly or upon the petition of 15 per cent of the qualified electors computed on the total vote for governor at the last election. The freeholders now have one hundred and twenty days in which to complete their work (originally the period allowed was one hundred and later ninety days). Ample provision is made for the publication of the charter in papers of general circulation, within fifteen days after it has been filed by the free-

\footnotetext{
- E. F. Treadwell, Charter of San Francisco Annotated.

7 Amendment of 1887, Treadwell, Constitution of California, p. 350.

${ }^{8}$ Statutes of 1889, pp. 415, 513, 577, 643.

9 Amendment of 1892, Treadwell, Constitution of California, p. 349.

${ }^{10}$ Original section, Treadwell, Constitution of California, p. 353.

11 Amendment of 1902, Treadwell, Constitution of California, p. 347.

12 Blanchard vs. Hartwell, 131 Cal., 263.

${ }^{13}$ Amendment of 1906, Treadwell, Constitution of California, p. 345.
} 
holders with the city clerk. Not less than twenty nor more than forty days after the completion of publication it is submitted to the people at a special election, and if approved by a majority of those voting, it is ready for presentation to the legislature at its next regular or special session. Legislative approval being forthcoming, as it always is, one copy certified by the mayor and authenticated by the seal of the city, is deposited with the secretary of state and one copy, after being recorded in the office of the county recorder, in the archives of the city. The process of amendment is similar except that the services of freeholders are not required. ${ }^{14}$

In all, thirty-one cities have availed themselves of the opportunity of making their own form of government. ${ }^{15}$ They include all the considerable urban communities of California and many of the smaller ones. The census of 1910 shows that there are fifty-two incorporated places in California with a population of 3500 or over. Of these, twenty-three had a population of less than 3500 in 1900 . Six out of the twenty-three having at various times passed the 3500 mark have adopted freeholder charters. Among the cities which have for ten years or more possessed the requisite number of inhabitants only Bakersfield (12,727), Santa Ana (8429), Redlands $(10,449)$ and Santa Clara $(4348)$ have not now freeholder charters. ${ }^{16}$ Several cities have adopted two charters and amendments have been frequent, Los Angeles leading with amendments every two years since 1903. Sometimes these amendments, as in the case of those proposed by San Francisco in 1910 and Los Angeles in 1903, are very extensive, amounting practically to new charters.

It is thus obvious that the freeholder charter privilege has been largely employed-by California cities. That it has been used on the whole wisely, no one can deny. Our cities are on the average well governed as compared with the country at large and where deficiencies exist they are due not so much to the frame of government as to political conditions which would pervert any charter no matter how excellent. At any rate the people are contented in the knowledge that full control of the machinery of government is in their hands. Our boards of freeholders have not been bold enough to "cast off their moorings from the habitable past." Until the last four years they followed pretty closely in the beaten track of municipal develop-

${ }^{14}$ Constitution of California, art. xi, sec. 8. As amended by amendment approved October 10, 1911.

${ }^{16}$ Statutes 1889 to 1911 (Extra Session).

${ }^{16}$ Freeholder charters have been ratified by the legislature as follows: 1889-Los Angeles, Oakland, Stockton, San Diego; 1893-Grass Valley, Napa, Sacramento; 1895-Berkeley, Eureka; 1897-San Jose; 1899-San Francisco, Santa Barbara, Vallejo; 1901-Fresno, Pasadena; 1903-Salinas, Santa Rosa, Watsonville; 1905-San Bernardino, Santa Rosa; 1907-Alameda, Long Beach, Riverside, Santa Cruz, Santa Monica; 1909 -Berkeley, Palo Alto, Richmond; 1911-Vallejo, Santa Cruz, San Luis Obispo, Pomona, Petaluma, Oakland, Monterey, Modesto, Stockton and Sacramento. 
ment. They have not revolutionized municipal government, being unable, perhaps happily, to divorce themselves from custom and tradition. On the whole, however, and especially of recent years, they have used their power progressively. The San Francisco charter of 1899 applied imperfectly the principle of the initiative and referendum. ${ }^{17}$ The Fresno charter of 1901 provided for the initiation of ordinances by a petition of 15 per cent of the voters. ${ }^{18}$ The Los Angeles charter amendments of 1903 introduced the "recall" to American municipal affairs and the language of that charter in providing for that trilogy of progressivism, the initiative, referendum and recall, has been copied verbatim into great numbers of recent charters. ${ }^{19}$ The commission form of government was taken up in 1909 by Berkeley ${ }^{20}$ and San Diego, 41 the former the most advanced features, the non-partisan nomination and majority election, of the Des Moines plan were copied with progressive modifications. The Berkeley election plan permits a majority on the first ballot to elect without further contest. ${ }^{22}$ At the regular session of 1911 the legislature ratified eight charters of which six, including that of Oakland, the largest city in the country to adopt the commission plan so far, provided for that form of government. ${ }^{23}$ At the same time San Francisco secured amendments which give her practically the terms of the Berkeley charter as to the initiative, referendum and recall and non-partisan nominations and elections. ${ }^{24}$ A large part of the credit for the overthrow of the corrupt political forces of San Francisco in the fall of 1911 is ascribable to these improvements-self-made-in its charter. At the special session of 1911 two more charters, both of the commission variety, were presented to the legislature, from Stockton and Sacramento. ${ }^{25}$ The latter provides for the shortest of ballots, one only of the five commissioners being chosen each year. There, too, the majority non-partisan election system helped to down a few weeks ago, one of the worst and ablest rings in California. I think it is safe to conclude that while cities under the freeholder system do not adopt certain reforms like commission government so speedily as if the legislature presented them ready made for simple adoption, they are by no means backward in working such reforms out for themselves. A new pattern or cut in ready-made clothing will get on more backs in shorter space than the same style in custom garments. It is, however, the latter which fit the eccentricities of figure and provide the full and scant in their proper locations. We have enjoyed all the advantages of special legislation without its evils. We have charters which meet each peculiar need and they are in the main as progressive as we might hopefor.

${ }^{17}$ E. F. Treadwell, Charter of San Francisco, art. ii, ch. 1, pars. 20, 21, 22.

18 Laws of 1901, p. \$32, \$277.

${ }^{19}$ Laws of 1903 , pp. 572-575.

${ }_{22}$ Berkeley charter, art. vi.

${ }^{20}$ Laws of 1909 , p. 1208.

${ }^{21}$ Laws of 1909 , p. 1137.

23 Laws of 1911.

${ }^{24}$ Laws of 1911, pp. 1670-1685.

${ }^{25}$ Laws of 1911 (Extra Session), 254, 305. 
When, however, we say that we have good and suitable charters under the freeholder system, we know that we have not told the whole story for any person cognizant of the usual relations of state and city. Cities may have the right to draft their own charters and amend them at will, but if the legislature may by its enactments override charter provisions, the city's liberty is merely nominal. The evil from which California cities suffered prior to 1879 was special legislation. Not only were all charters specially granted but the statute books were crowded with special acts for particular cities. For the purpose of illustration let us take the single city of San Francisco and see what legislation was passed for it in a year selected at random, say 1869 . In that year ${ }^{26}$ fifty special acts were passed for San Francisco, many of them containing numerous items. Only two were ostensibly charter amendments, the remainder being merely special acts authorizing or providing such important things as the appointment of deputies in the assessors office, ${ }^{27}$ the employment of one janitor at $\$ 75$ per month, ${ }^{28}$ the opening and establishment of a street by name, ${ }^{2 .}$ the appropriation of $\$ 5000$ to the Sisters of Mercy for services in a smallpox epidemic. ${ }^{30}$ That these are not extreme examples of legislative interference may perhaps be seen from the following pious title, "An Act to authorize the Mayor and Common Council of the City of Marysville to close up Virgin Alley between Seventh and Eighth Streets." ${ }^{\prime 3}$ 'Altogether these special acts made a state of confusion in the legal basis of power of every city which even a Philadelphia lawyer would have hesitated to precipitate in the service of the richest of corporations. These measures were generally of local origin. Indeed, legislative interference with city government is practically always of local origin. I was present in the New York assembly when the famous ripper bill depriving Ogdensburg of its charter to oust a Democratic administration was put through. There was no doubt of its local authorship. The difficulty with special legislation is not the place from which but the persons from whom it emanates. Sometimes it comes from the people or representative citizens, but more frequently from disgruntled minorities and sinister groupings of the ill-disposed.

So grave an evil had this become by 1879 that the members of the constitutional convention set their faces sternly against it. They prohibited all local and special laws in thirty-three enumerated cases embracing practically every subject on which such legislation might be framed.52 They further provided that corporations for municipal purposes should not be created by special laws, but by general laws according to a scheme of classi-

\footnotetext{
26 Laws of 1869.

27 Laws of 1869 , ch. 22.

${ }^{28}$ Laws of 1869 , ch. 174.

${ }^{29}$ Laws of 1869 , ch. 361.

${ }^{30}$ Laws of 1869 , ch. 171.
} 
fication to be provided by the legislature. ${ }^{33}$ The section in question closed with these words: "and cities and towns heretofore or hereafter organized, and all charters thereof framed or adopted by authority of this constitution, shall be subject to and controlled by general laws. ${ }^{34}$ By this means such control as the legislature might exercise over any city, whether possessing a freeholder charter or not, must be by general law.

As is well known, the attitude of the courts has been so liberal that a legislature may exercise a good deal of local power through laws general, at least in form. California was no exception to this rule. In the leading case of Brooks vs. Hyde, ${ }^{35}$ Sanderson J. said: "The word 'general' comes from genus, and relates to a whole genus, or kind, or in other words, to a whole class or order. Hence a law which affects a class of persons or things less than all, may be a general law." Under this ruling, although the opportunity for interference with local independence by statute was greatly reduced, it was by no means abolished. This led to the adoption of a constitutional amendment in November, 1896, inserting the word "except in municipal affairs" immediately before the words "shall be subject to and controlled by general laws." The phrase "except in municipal affairs" has closed the last aperture through which the legislature might even covertly, and by indirection, deprive a city of its liberty. It makes the California city the best protected in the United States against the corrupt or misguided efforts of outsiders to save her from herself.

The meaning of the term "municipal affairs" is no longer doubtful. In the first place it refers to the internal business affairs of the city and not to its external relations. For instance, the method of conducting charter elections, ${ }^{36}$ and the procedure for the annexation of contiguous territory, ${ }^{37}$ are not "municipal affairs." Neither are the trial and punishment of offenses defined by the laws of the state ${ }^{38}$ and the power of the state to pass laws for the protection of the health and safety of the people is not diminished. On the other hand an act to require ordinances and resolutions passed by the city council to be presented to the chief executive officer of the municipality, for his approval, is invalid as against a contrary charter provision $;^{30}$ while such matters as the compensation of municipal officers, ${ }^{40}$ the management of hospitals and almshouses, ${ }^{41}$ imposing license taxes for revenue, ${ }^{42}$ and opening streets, ${ }^{43}$ have been held to be municipal affairs.

\footnotetext{
${ }^{33}$ Constitution of California, art. xi, sec. 6.

${ }^{34}$ Constitution of California, art. xi, sec. 6; original section. See Treadwell, Constitution of California, p. 310 .

${ }^{35} 37$ Cal. $366,376$.

${ }^{30}$ Fragley vs. Phelan, 126 Cal. 383.

${ }^{37}$ People vs. Oakland, 123 Cal. 598.

${ }^{39}$ Robert vs. Police Court.

${ }^{39}$ Morton vs. Broderick, 118 Cal. 487.

40 Popper vs. Broderick, 123 Cal. 456 ; Elder vs. McDougald, 145 Cal. 740.

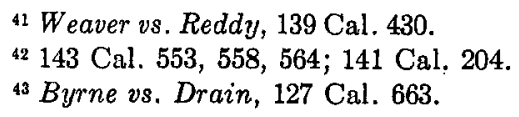

41 Weaver vs. Reddy, 139 Cal, 430.

42143 Cal. 553, 558, 564; 141 Cal. 204.

${ }^{43}$ Byrne vs. Drain, 127 Cal. 663. 
A charter board of health may supplant a board provided by a state law, although this does not mean that a central state board of health may not have jurisdiction within a city. ${ }^{44}$ It has even been held that bonds voted under the park and boulevard act, but not sold at the time a charter containing different provisions on this subject takes effect, cannot be issued. ${ }^{45}$

The net result of all these measures for protecting city independence against the legislative activity of the state is perhaps best indicated by an analysis of the legislation of 1911 . This was the most prolific legislature which ever sat in California. There were, however, not over ten laws directly affecting cities other than those organized under general laws. Among these were the tenement house act ${ }^{46} \mathrm{a}$ clear and very proper exercise of the police power of the state, and an act requiring the compilation and publication 'by the comptroller of the financial transactions of all counties and municipalities, ${ }^{47} \mathrm{a}$ most salutary measure of the right kind of state control. Several measures were indeed passed, some half dozen in all, at the instance of the city of San Francisco. Some of them were legalizing bond issues which have received a two-thirds popular vote ${ }^{48}$ providing for the removal of remains from cemeteries.$^{49}$ and for the opening of streets through cemeteries, ${ }^{50}$ amending the civil code relative to the use of the same tracks by two lines of street railway ${ }^{51}$ and an act making the use of a public service system by a municipality a more necessary use than the use of the same system by a private corporation..$^{52}$ There is certainly no objection to these measures in form or in principle. The city simply comes and asks changes in general laws to relieve it from some disability or to secure some advantage, which relief or advantage sound policy may well demand should be granted to all cities. Most legislation originates with localities or individuals in this way and must inevitably do so. The curse of legislative interference is a thing of the past in California.

There remains only to speak briefly of two more provisions of the constitution. One of these was a most unfortunately inconsistent limitation on the liberty of municipalities. Section 19 of article xi until this year provided that in a city where there were no public works owned by the city for supplying water or artificial light, any person or corporation might lay wires or pipes in the streets of the city upon the simple conditions that the city might lay down rules as to damages and regulate rates. ${ }^{53}$ This provision destroyed the effect of the system of competitive bidding for franchises inaugurated by the San Francisco charter of 1899 and was generally

“ People vs. Williamson, 135 Cal. 415.

${ }^{45}$ Fritz vs. San Francisco, 132 Cal. 373.

49 Laws of 1911, ch. 577.

${ }^{46}$ Lawsof 1911, ch. 432.

50 Laws of 1911, ch. 578.

${ }^{47}$ Laws of 1911, ch. 550.

11 Laws of 1911 , ch. 580 .

18 Laws of 1911, eh. 234.

${ }^{52}$ Laws of 1911, ch. 358.

${ }^{53}$ Art. xi, sec. 19, original section Treadwell, Constitulion of California, p. 404. 
harmful..$^{54}$ An amendment of 1911 substituted for it this language, "Persons or corporations may establish and operate works for supplying the inhabitants with such services upon such conditions and under such regulations as the municipality may prescribe under its organic law . . . ." At the same time the right of a municipality to own and operate its own utilities was made clear and certain. ${ }^{55}$ The other is a board grant of power, unusual in the generality of its terms, to cities and counties. Section 11 of article xi provides, "Any county, city, town, or township may makt and enforce within its limits all such local, police, sanitary, and other regulations as are not in conflict with general laws." This approaches in magnitude those general grants of power which are so of ten the theme of the admirers of European city governments. It is the capstone of our system of municipal independence.

To sum up the privileges of California cities: (1) They may make their own charters subject to a formal submission to the legislature which always approves them; (2) These charters prevail over general laws, even, in all matters affecting the internal affairs of the municipality; (3) Special or local laws are forbidden; (4) They may adopt any kind of ordinance or regulation even outside the field of strictly "municipal affairs" not inconsistent with the general laws of the state. Our cities are the freest on earth. Perhaps indeed they are too free because they are scarcely at all subject to those modes of administrative supervision which work out so well in other countries. In this respect, however, they are gradually losing their isolate position. To show how much in dollars and cents we have gained by this system would be impossible. It is even hard to estimate our gains in popular satisfaction and in the convenience of not being obliged to persuade a third party to minor changes in our government. It is not unlikely that our greatest benefit has come from the tricks that have not been played, the deceptions which have not been practised, the graft that has "died aborning." No one can measure exactly such advantages but we all know that we enjoy them and that they are great.

${ }^{54}$ Charter of San Francisco, art. ii, ch. ii, sec. 7.

${ }^{55}$ Constitution of California, art. xi, sec. 19. 